\title{
GAYA RETORIKA PASANGAN KANDIDAT CAGUB \& CAWAGUB DKI DALAM DEBAT POLITIK
}

\author{
Agusly Irawan Aritonang \\ Universitas Kristen Petra Surabaya \\ Jalan Siwalankerto No. 121-131 Surabaya 60236 \\ email: agusly_irawan@yahoo.com
}

\begin{abstract}
The local leaders election of DKI is an example of arena in which the candidates play their own political rhetoric to fight for the voters' heart. Through the political debates, the candidates have the chances to explain who they are, their vision, and the programs they want to do. With the specific rethoric style, a candidate as a political comunicator has a chance to comunicate with the audiences as well as to impress them as the final goal. This study tries to capture how the styles of political rhetoric of each candidate, both candidates for governor and vice governor are demonstrated. This study on debate video of candidates for governor and vice governor of DKI using qualitative content analysis, discovers a scheme of rhetoric style of Agus Yudhoyono which combines rhetoric style of exhortative, bureaucratic. Syliviani Murni puts priority on bureaucratic, formal, and exhortative. Basuki Tjahjana Purnama tends to be outspread because of combining open, bureaucratic and formal. On the other hand, Djarot is more familiar with the rhetoric style of bureaucratic and exhortative. Anies Basewedan is so intense with the aspect of personal branding and the combination of bureaucracy and exhortative. Sandiaga Uno tends toward rhetoric to emphasize the personal branding.
\end{abstract}

Keyword : style of political rhetoric, the local leader election of DKI, political communication.

\begin{abstract}
ABSTRAK
Pilkada DKI merupakan satu contoh arena dimana kandidat memainkan retorika politiknya untuk merebut hati pemilik suara. Melalui acara debat politik, kandidat memaparkan siapa dirinya, visi-misi dan program yang ingin dilaksanakan. Dengan gaya retorika yang khas, kandidat selaku komunikator politik memiliki kesempatan berkomunikasi dengan audiens sekaligus mempengaruhi mereka. Penelitian ini bertujuan memotret gaya retorika politik masing-masing calon, baik calon gubernur maupun calon wakil gubernur dalam video debat kandidat Cagub dan Cawagub DKI. Penelitianyang menggunakan metode analisis isi kualitatif ini menemukan pola gaya retorika Agus Yudhoyono yang menggabungkan gaya retorika nasihat, birokratis. Sylviani Murni lebih mengedepankan gaya birokrat, formal dan nasihat. Basuki Tjahjana Purnama cenderung lebih tersebar, karena mengkombinasikan gaya terbuka, birokratis, formal. Sedangkan Djarot lebih mengemuka dengan gaya retorika birokratis dan nasihat. Anies Baswedan sangat kuat dengan aspek personal branding dan kombinasi birokrasi serta nasihat. Sandiaga Uno lebih mengarah ke retorika untuk menonjolkan personal branding.
\end{abstract}

Kata kunci: Gaya Retorika Politik, Pilkada DKI, Komunikasi Politik

\section{Latar Belakang}

Pada tahun 2017 terjadi

penyelenggaraan 101 pilkada serentak di

Indonesia. Pilkada ini bertujuan memilih

pemimpin di wilayah atau tingkat lokal

mulai gubernur maupun bupati. Pilkada sebagai manifestasi demokrasi dengan

partisipasi langsung dari pemilik hak suara menjadi momentum sangat penting demi kemajuan daerah tersebut sekaligus perkembangan demokrasi. 
Salah satu daerah atau provinsi yang mengadakan pemilihan kepala daerah adalah DKI Jakarta. Pilkada DKI Jakarta diikuti 3 pasangan yaitu Agus Harimurti Yudhoyono dan Sylviana Murni (nomor urut 1), Basuki Tjahja Purnama dan Djarot Saiful Hidayat (nomor urut 2), serta Anies Baswedan dan Sandiaga Uno (nomor urut 3). Ketiga pasangan ini mengikuti kegiatan pilkada DKI mulai pendaftaran paslon pada 21-23 September 2016, penetapan paslon pada 24 Oktober 2016, masa kampanye mulai 28 Oktober 2016 - 11 Februari 2017. Sedangkan masa pemungutan suara berlangsung pada 15 Februari 2017 dan pemenang diumumkan pada 4 Mei 2017.Hasilnya Anies Sandi memenangkanPilkada DKI.

Ada beberapa alasan yang membuat pilkada DKI perlu dicermati. Pertama, DKI merupakan ibukota Negara Republik Indonesia sehingga pilkada DKI bisa dijadikan barometer kesuksesan pilkada serentak. Kedua, yang terlibat sebagai pasangan calon di merupakan tokoh yang memiliki reputasi nasional, seperti Anies Baswedan yang sebelumnya menjabat Menteri Pendidikan, Agus Harimurti Yudhoyono yang merupakan putra sulung mantan Presiden RI Susilo Bambang Yudhoyono, maupun incumbent yaitu Basuki Tjahja Purnama atau Ahok. Ketiga, dinamika pilkada DKI yang dinamis menjadi hal yang sangat menarik dicermati. Kedinamisan ini bisa ditarik ke belakang dan mulai terlihat ketika dibukanya pendaftaran. Ada beberapa tokoh yang digadang-gadang mengikuti pilkada seperti Yusril Ihza Mahendra, Abraham Lunggana atau Haji Lulung meski akhirnya gagal. Proses pun semakin dinamis karena terjadi beberapa kejutan seperti hadirnya Anies Baswedan yang baru saja di-reshuffle dari Kabinet Presiden Jokowi. Di saat yang lain koalisi yang dibangun Partai Demokrat mengusung Agus Harimurti Yudhoyono yang merelakan kariernya di TNI. Proses pilkada DKI semakin dinamis ketika Basuki Tjahja Purnama atau Ahok 
ditetapkan sebagai tersangka dalam kasus dugaan penistaan agama. Kesemuanya ini menjadi pertimbangan mengapa pilkada DKI menjadi menarik dicermati.

Proses memenangkan pertarungan dalam pilkada merupakan proses memenangkan hati pemilik suara. Untuk memenangkan proses tersebut diperlukan proses komunikasi dari pasangan calon kepada pemilih. Sebagai proses komunikasi tentu diperlukan strategi dalam mengkomunikasikan kekuatan pasangan calon. Terutama dalam masa kampanye, mengkomunikasikan hal yang berkaitan dengan visi misi, program kerja dan aksi pasangan calon merupakan momentum yang harus dimanfaatkan sebaik-baiknya.

Retorika merupakan kajian yang sudah lama ada dalam riset politik maupun praktik komunikasi. Retorika diyakini sebagai bentuk penyampaian pesan tertentu oleh kandidat politik (dalam konteks politik) kepada audiens untuk penegasan isu tertentu. Beberapa riset terkait retorika seperti Kertanegara dan
Wahyuni (2013) yang meneliti gaya retorika peserta Konvensi Calon Presiden Partai Demokrat di halaman Facebook untuk melihat keterkaitan latar belakang kandidat dengan gaya retorikanya. Selain itu ada riset Ricky dan Rejeki (2014) yang mencermati aspek retorika dalam Debat Capres 2014 antara Prabowo Subianto dan Joko Widodo. Jika pada riset Kertanegara studi gaya retorika dilakukan pada halaman media sosial Facebook dengan menggunakan analisis kuantitatif, maka riset ini menggunakan analisis isi kualitatif dari acara debat kandidat. Sedangkan bila dibandingkan dengan riset Ricky dan Rejeki yang mencermati aspek ethos patos dan logos dari retorika kandidat, maka riset ini menggunakan kategori gaya retorika.

Sebagai proses komunikasi, penyampaian pesan ditujukan kepada komunikan. Unsur-unsur terkait retorika politik haruslah sampai dan diterima komunikan yang menjadi pemilik suara agar mereka bersedia memberikan suara 
dalam pemungutan suara. Tentu saja, retorika kandidat haruslah ditangkap dan menghasilkan persepsi positif di benak komunikan sehingga apa yang dibangun kandidat mulai citra diri, visi misi dan gagasan bisa diterima.

Penelitian ini berfokus pada gaya retorika politik cagub dan cawagub DKI dalam video debat publik yang diselenggarakan KPUD DKI. Penelitian ini menggunakan video debat politik yang dilakukan secara resmi oleh KPUD DKI selama masa kampanye, yaitu 13 Januari 2017 dan 27 Januri 2017.

\section{Tinjauan Pustaka}

Komunikasi Politik

Dahlan (1999) menyampaikan, komunikasi politik dipahami sebagai bidang atau disiplin yang menelaah perilaku dan kegiatan komunikasi yang bersifat politik, mempunyai akibat politik, atau berpengaruh terhadap perilaku politik. (Cangara,2009: 35). Lebih jauh komunikasi politik bisa merujuk proses pengoperan lambang atau simbol komunikasi yang berisi pesan politik dari seseorang atau kelompok kepada orang lain dengan tujuan membuka wawasan atau cara berpikir, serta memengaruhi sikap dan tingkah laku khalayak yang menjadi target politik.

Pendapat lain tentang komunikasi poltik disampaikan Mc Nair yang menyatakan:"political communication as pure discussion about the allocation of public resources (revenues), official authority (who is given the power to make legal, legislative and executive decision), andofficial sanctions ( what the state reward or punishes)." Mc Nair lebih menitikberatkan komunikasi politik sebagai alokasi sumber daya publik yang memiliki nilai, apakah itu nilai kekuasaan atau nilai ekonomi, petugas dalam pembuatan undang-undang atau aturan, apakah itu legislatif atau eksekutif, serta sanksi-sanksi, apakah dalam bentuk hadiah atau benda. Dengan begitu jelas penekanan komunikasi politik adalah proses 
komunikasi yang memiliki implikasi atau

konsekuensi terhadap aktivitas politik.

(Cangara,2009: 36)

Sebagai proses komunikasi, komunikasi politik pun memiliki beberapa unsur:

1. Komunikator politik

Tidak hanya terbatas

partai politik, melainkan

juga lembaga

pemerintahan legislatif

dan eksekutif.

Komunikator politik

adalah mereka yang

dapat memberi

informasi tentang hal-

hal yang mengandung

makna atau bobot

politik, misalnya

presiden, menteri,

anggota DPR,MPR,

KPU, gubernur,

bupati/walikota, DPRD,

politisi, fungsionaris

partai politik, fungsionaris lembaga

swadaya masyarakat

(LSM), dan kelompok

penekan yang bisa

mempengaruhi

pemerintahan.

2. Pesan politik

Merujuk pernyataan

yang disampaikan, baik

secara tertulis maupun

tidak tertulis, verbal

maupun non verbal,

tersembunyi maupun

terang-terangan,

disadari maupun tidak

disadari, yang isinya

mengandung bobot

politik.

3. Saluran atau media

politik

Alat atau sarana yang

digunakan komunikator

dalam menyampaikan

pesan politiknya.

Misalnya : 
a. Media cetak seperti

suratkabar, tabloid,

majalah,buku.

b. Media elektronik

seperti film, radio,

televisi, tabloid,

video, komputer,

internet.

c. Media format kecil

seperti leaflet,

brosur, selebaran,

tiker, buletin.

d. Media luar ruang

seperti baliho,

spanduk, reklame,

papan elektronik,

bendera, pin,

logo,topi,rompi,dll.

e. Saluran komunikasi

kelompok, misalnya

partai

politik,organisasi

profesi, ikatan

alumni,organisasi

sosial keagamaan, karang taruna,

kelompok

pengajian,dll.

f. Saluran komunikasi publik, misalnya aula, balai desa, pameran, alun alun, panggung kesenian,pasar, swalayan, sekolah, kampus.

g. Saluran komunikasi sosial, misalnya pesta perkawinan, arisan, acara sunatan, pesta rakyat,dll.

4. Sasaran atau target politik.

Yaitu anggota

masyarakat yang

diharapkan memberi

dukungan dalam bentuk pemberian suara kepada partai atau kandidat. 
5. Pengaruh atau efek komunikasi politik

Efek komunikasi politik yang diharapkan adalah terciptanya pemahaman terhadap sistem pemerintahan danpartai politik, di mana nuansanya bermuara pada pemberian suara dalam pemilihan umum. (Cangara, 2009: 37-39)

Komunikasi politik memiliki beberapa fungsi. Mc Nair (2003) menyampaikan 5 fungsi dasar komunikasi politik, yaitu :

1. Memberikan informasi kepada masyarakat apa yang terjadi di sekitarnya. Di sini media komunikasi memiliki fungsi pengamatan dan monitoring apa yang terjadi dalam masyarakat.
2. Mendidik masyarakat terhadap arti dan signifikansi fakta. Di sini jurnalis diharapkan melihat fakta sehingga membuat liputan objektif yang mendidik masyarakat atas realitas fakta tersebut.

3. Menyediakan diri sebagai platform untuk menampung masalah politik sehingga bisa menjadi wacana dalam membentuk opini publik, dan mengembalikan hasil opini itu kepada masyarakat. Dengan demikian, bisa memberi arti dan nilai pada usaha penegakan demokrasi.

4. Membuat pubilkasi yang ditujukan kepada 
lembaga politik. Di sini

media

berfungsi

sebagai anjing penjaga

(watchdog).

5. Dalam masyarakat

demokratis, media

politik berfungsi

sebagai saluran

advokasi yang

membantu agar

kebijakan dan program

lembaga politik dapat

disalurkan kepada

media massa.

\section{Retorika Politik}

Retorika bisa dipahami sebagai

kemampuan yang dimiliki pembicara untuk memengaruhi khalayak. (Turner \& West, 2007: 39). Retorika yang erat kaitannya dengan dunia perpolitikan merupakan komunikasi dua arah dimana komunikator berusaha memengaruhi komunikan yang bertujuan mendapatkan dukungan, respon, dan simpati. Lebih jauh
Hendrikus (1991) menyebut retorika sebagai seni berbicara, baik yang didapat melalui bakat alam(talenta) dan keterampilan teknis. Retorika sendiri membutuhkan dialektika (diskusi \& debat) dan elocutio atau kelancaran berbicara.

Nimmo ( 1978) menyampaikan 5 gaya retorika komunikasi politik:

1. Nasihat (exortive); gaya berbentuk nasihat dan cenderung desakan bahwa terdapat masalah dan perlu ada tindakan untuk segera dilakukan. Bentuk kampanye ini biasanya menggunakan metafora untuk menarik dukungan dan perhatian agar ikut bergabung dan mengikuti gameplan.

2. Resmi (legal); gaya yang bersifat resmi dan formal, seperti teks konstitusi, undangundang, perjanjian, dan lainlain, yang menyimbolkan legitimasi. Penggunaan gaya ini 
dapat membuka interpretasi

berbeda demi membenarkan

tindakan dan kepentingan

mereka.

3. Birokratik (bureaucratic); gaya berbentuk jargon teknis atau sulit dipahami. Sering diasosiasikan dengan peraturan, kebijakan, dan tindakan penyelia yang berhadapan dengan masyarakat umum dan satu sama lain. Seperti gaya resmi, dapat terjadi kecenderungan bertele-tele yang menimbulkan peluang mis-interpretasi kata-kata, frase, dan prosedur yang sangat ambigu.

4. Tawar-menawar (bargaining), kompromi politik dari take and give atau barter, atau jual-beli suara. Meskipun sering dikaitkan oleh warganegara dengan politik partisan, gaya ini juga terjadi di kalangan pejabat eksekutif dan yudikatif yang berusaha mewujudkan solusi.

5. Terbuka/tertutup (closed/open), gaya tertutup cenderung "defensif" dan hati-hati, komunikator cenderung enggan atau ragu menyerahkan kontrol atas informasi atau pengungkapan penuh rencana mereka. Gaya terbuka cenderung lebih spontan, kurang terprogram, mengungkapkan jati diri.(128129)

Gaya retorika dan personal branding merupakan gaya retorika yang langsung terkait dengan branding khususnya personal branding. Menurut Rampersad, branding merupakan hal memengaruhi orang lain dengan menciptakan brand identity yang mengasosiasikan persepsi dan perasaan yang terkait identitas tersebut. Sedangkan personal branding berfokus pada 
otentisitas dimana harus merepresentsikan karakter dan dibangun atas dasar cita-cita tujuan, nilai, keunikan, hasrat, spesialisasi, dan hal-hal yang dicintai. (Rampersad,2009:xi)

Sebagai proses komunikasi, penyampaian pesan ditujukan kepada komunikan. Unsur-unsur terkait retorika politik haruslah sampai dan diterima komunikan pemilik suara agar bersedia memberikan suara dalam pemungutan suara. Tentu saja, retorika kandidat haruslah ditangkap dan menghasilkan persepsi positif di benak komunikan sehingga apa saja yang dibangun kandidat mulai citra diri, penyampaian visi misi dan gagasan bisa diterima komunikan pemilik suara.

Debat politik merupakan acara yang menarik dicermati. Sebagai acara untuk mengenal calon dan programprogramnya, format debat menjadi ajang saling bertanya, mengkritisi bahkan menyerang kandidat baik. Penelitian Benoit (1999 \& 2002) menyebutkan, debat sangat fokus pada isu kampanye daripada karakter calon, calon dalam debat jauh lebih sering memuji diri daripada menyerang lawan.

Debat kandidat bisa dipahami sebagai wadah memasarkan diri, menjual visi misi dan program serta menunjukkan kandidat lebih baik dan lebih unggul dibanding lainnya. Terkait aspek memasarkan diri, konsep personal branding pun menjadi mengemuka. Personal branding sendiri dipahami sebagai seni menarik dan memelihara lebih banyak klien dengan membentuk persepsi publik secara aktif (Montoya, 2006). Personal branding juga dipahami sebagai bagaimana mengambil kendali atas penilaian orang lain terhadap Anda sebelum ada pertemuan langsung dengan Anda. (Montoya \& Vandehey 2008).

\section{Metode}

Penelitian ini merupakan penelitian deskriptif dengan pendekatan kualitatif yang menggunakan metode analisis isi 
kualitatif.Subjek penelitian adalah video debat kandidat Cagub dan Cawagub DKI yang diselenggarakan KPU DKI pada 13 Januari 2017 dan 27 Januari 2017. Sedangkan obyek penelitian adalah gaya retorika kandidat baik Cagub dan Cawagub DKI. Data rekaman video debat Cagub dan Cawagub DKI diperoleh melalui youtube.

\section{Pembahasan}

\section{C.1. Gaya Retorika Agus Harimurti Yudhoyono (AHY)}

Agus Harimurti Yudhoyono atau AHY pada debat 1 memainkan beberapa gaya retorika politik. Gaya yang dominan ia gunakan dalam debat 1 ini adalah gaya retorika nasihat. Gaya retorika ini bisa dicermati dari pemaparan problem warga Jakarta lalu diikuti tindakan yang perlu diambil untuk menyelesaikan persoalan tersebut. Contoh retorika nasehatAHY antara lain terlihat ketika ia membuka debat awal dengan pernyataan:

"Selain yang sudah baik, potret hidup, kualitas hidup masyarakat menurun akibat banjir, macet, sampah yang tidak dapat diselesaikan dengan baik. Dan yang paling menyedihkan adalah di sana sini warga Jakarta banyak yang takut dengan pemerintahannya sendiri.Visi saya lima tahun ke depan adalah menjadikan Jakarta semakin maju, aman, adil dan sejahtera. Komitmen saya dan tentunya misi saya adalah mengatasi semua permasalahan di Jakarta, meningkatkan pembangunan sehingga Jakarta semakin maju kedepan dengan cara pertama meningkatkan ekonomi daerah, meningkatkan daya beli masyarakat, dan menciptakan lapangan kerja baru. Kedua, meningkatkan kualitas pendidikan, pelayanan kesehatan dan transportasi umum. Ketiga, meningkatkan kualitas lingkungan hidup dengan cara solusi yang efektif untuk mengatasi problem akut seperti banjir, sampah dan polusi. Terakhir dan tidak kalah penting adalah meyakinkan hadirnya rasa aman dan adil untuk seluruh warga Jakarta.”

Pada statement pembuka ini AHY menyampaikan ada problem warga Jakarta seperti menurunnya kualitas hidup akibat banjir, macet, sampah yang tidak diselesaikan dengan baik serta adanya ketakutan akan pemerintahannya sendiri. Untuk menyelesaikan persoalan itu AHY menyampaikan program kerjanya. 
Gaya retorika nasihat atau exhortivejuga muncul untuk menjawab pertanyaan moderator. Ketika menjawab pertanyaan moderator terkait penggusuran, gaya nasihat atau exhortivedimainkan AHY.

"Dengan tegas $r \begin{array}{r}\text { saya } \\ \text { mengatakan,kami }\end{array}$ akan
membangun dan menata Jakarta
tanpa menggusur. Mengapa?
Karena penggusuran hanya akan
meningkatkan kemiskinan. Urban
Poverty meningkat secara tajam.
Mereka akan kehilangan
segalanya. They lost everything.
Kehilangan tempat tinggal, mata
pencaharian. Yang tadinya bekerja
dalam habitat, interaksi dengan
tetangga dengan warga tiba-tiba
tercabut puluhan kilometer. Tanpa
diperitungkan nasib selanjutnya....
Kami meyakini banyak cara
menata kota Jakarta untuk
mempercantik kotanya. Tetapi
dengan tidak melukai hati
warganya. Ini penting. Ini
komitmen dan ini adalah
paradigma akan kami bangun
dalam membangun Jakarta.
Dengan demikian kami berharap
Jakarta benar benar tumbuh
sebagai kota yang manusiawi...
Jakarta rohnya adalah manusia
dan warganya. Sistem ruang
kehidupan merupakan tempat
interaksi antara manusia
lingkungan dan semua sarana
prasarana di dalamnya. Dengan
demikian jangan kita hanya
membangun badannya tetapi
bangunlah jiwa kota ini. Jakarta
untuk Indonesia..."

Gaya retorika nasihat pada argumen ini lebih ke arah menampilkan persoalan bahwa dengan penggusuran akan ada dampak yang diakibatkan,baru kemudian diarahkan ke tindakan yang akan diambil pasangan AHY-Sylvi. Agus juga menggunakan metafora untuk mengibaratkan Jakarta dengan istilah “sistem ruang kehidupan.” Penggunaan metafora ditujukan untuk menarik dukungan dan perhatian agar mau ikut bergabung dan mengikuti gameplan. Ajakan AHY untuk mau bergabung menata Jakarta sebagai sistem ruang kehidupan dilanjutkan dengan statement: "Kita bisa kalau kita bersatu kreatif dan juga dengan akal dan hati nurani.”

Dalam debat kedua, AHY mengkombinasikan gaya retorika lain selain nasihat. Memang secara dominan AHY masih mengutamakan gaya retorika nasihat dengan pemaparan persoalan yang muncul kemudian langkah yang perlu diambil. Untuk langkah yang perlu 
diambil, maka program kerja, visi misi menjadi jawaban atas persoalan tersebut.

Gaya retorika nasihat bisa dicermati berupa gambaran Jakarta haruslah menjadi rumah yang nyaman serta mensejahterakan seluruh warganya. Dia menggunakan metafora “Jakarta sebagai sebuah sistem ruang kehidupan.”Untuk mewujudkan nasehat tersebut, AHY menyampaikan tindakan yang perlu dilakukan yang tercetus menjadi visi 5 tahun. AHY juga menyoroti kinerja birokrasi di DKI Jakarta. Dengan gaya retorika nasihat, AHY memaparkan problem pola kepemimpinan di Pemprov DKI yang tidak konstruktif dengan memberikan argumen karena birokrasi yang dibangun dengan rasa takut berdampak pada rendahnya ranking kinerja aparatur sipil DKI.

"Banyak sekali daerah yang masih sangat kotor. Masih sangat menyedihkan kondisinya. Jadi saya menduga justru karena birokrasi yang dibangun selama ini penuh rasa takut, diancam kamu dicopot, dimutasi, dipindahkan, dipenjarakan dipamerkan ke depan publik. Harga diri dihancurkan padahal dia punya keluarga, teman, kerabat. Tetapi tidak dipedulikan itu semua karena alasannya ingin meningkatkan kinerja birokrat. Bagi saya itu bukanlah sesuatu yang konstruktif. Justru sebaliknya....”

Namun AHY juga menampilkan aspek personal branding yang ia tunjukkan ketika memposisikan dirinya sebagai seorang berlatar belakang belakang militer yang diyakininya memiliki sistem jelas dan terukur dalam penataan organisasi profesional. Dengan branding mantan militer, dia membangun persepsi terbiasa dengan lingkungan terukur dan menata organisasi dengan profesional. Hal itu ia manfaatkan dalam menata struktur birokrasi di DKI Jakarta yang merupakan wilayah sipil. Hal ini bisa dicermati dari statement AHY yang menyatakan:

$$
\begin{aligned}
& \text { “....Tadi benar dikatakan } \\
& \text { adanya intervensi intervensi } \\
& \text { dari kekuasaan politik yang } \\
& \text { harus kita hindarkan. Tentu } \\
& \text { saya akan mengadopsi apa } \\
& \text { yang menjadi modal saya }
\end{aligned}
$$


selama di militer bagaimana menata organisasi profesional dan juga memiliki merit system yang serba terbuka dan terukur. Tentu kita menggunakan key performance indikator yang terukur untuk tiap jabatan. Kita yakinkan bahwa setiap birokrat menduduki jabatan sesuai spesialisasi dan kemampuannya. The right man on the right place..."

Secara pola bisa dilihat Agus

menyampaikan retorikanya, visinya

terkait bagaimana seharusnya

birokrasi yang harus dijalankan di

pemprov DKI. Agus membangun

persepsi di masyarakat terkait

backgroundnya di militer yang

dikenal sebagai sistem yang

berpatokan pada standar yang terukur

dan menganut merit system yang

terbuka. Berdasarkan backgrund

tersebut Agus mencoba

merepresentasikan karakter yang

ingin membangun birokrasi yang

transparan, akuntabel dan terukur.

\section{C.2 Gaya Retorika Sylviana Murni}

Porsi penampilan Sylviana Murni

menjawab pertanyaan maupun bertanya

kepada calon lain lebih sedikit dibanding

AHY. Hal ini berdampak tidak terlalu tampaknya gaya retorika Sylvi. Baik dalam

debat 1 maupun 2, Sylvi lebih

menonjolkan retorika bergaya birokrasi

maupun resmi meskipun ada juga yang

bergaya nasihat layaknya AHY. Sylvi

secara implisit menggunakan retorika

bergaya birokrasi untuk menjelaskan hal-

hal teknis pemerintahan yang terkait

peraturan, tindakan, kebijakan penyelia

yang berhadapan dengan tindakan umum.

Hal ini bisa dicermati dari argumen Sylvi

berikut:

“....Saya betul-betul berpikir bahwa masyarakat Jakarta butuh lapangan pekerjaan. Pengawasan orang asing. Saya mantan kepala dinas kependudukan DKI Jakarta. Saya tahu bagaimana dokumen-dokumen ini paling penting diawasi. Ketika orang asing datang mulai masuk terus kita lihat lagi bagaimana dokumen kependudukan itu apakah sudah memenuhi persyaratan dan yang paling penting lagi. Ini yang sering terjadi. Kita sekarang sudah punya elektronik KTP. Atau e-KTP. Satu Jakarta. Ini kartu kita. Yang semua dokumen kependudukan ada di sini. Nanti kita akan lihat apakah orang asing itu tepat..”

"Itu sebabnya saya mengeluarkan kartu Satu Jakarta. Kenapa? Karena saya melihat sendiri. Saya tahu 
betul di dalam belum jalan.

Karena itulah saya

mengatakan saya sudah siapkan aplikasi ini. Bicara di sini ada kartu Jakarta Pintar, disini ada education report. Bicara KJS ada medical report. Bicara transportasi, bicara bagaimana ini juga bisa menjadi ATM dan yang paling penting lagi kita gak repot. Data semua ada di sini. Dan saya yakin bahwa kalau kita memiliki Satu Jakarta ini..”

Sylvi menyampaikan pesan berupa jawaban teknis berupa isi kebijakan pengawasan orang asing dan mengasosiasikan diri sebagai birokrasi pemerintahan yang berhadapan dengan masyarakat, dan melanjutkan dengan kemunculan program kartu Satu Jakarta yang juga penyampaiannya bersifat penjelasan berupa kandungan yang dimiliki kartu Satu Jakarta. Retorika birokratis juga ditampakkan ketika dalam acara debat ke-2 Sylvi membahas kepegawaian di DKI. Ini bisa dicermati dari jawaban Sylvi untuk menanggapi pertanyaan Sandiaga Uno:

"UU No 5 tahun 2014 tentang ASN. Kita tahu betul bahwa beda dulu dengan sekarang. Ketika sebelum UU ASN, memang kita memakai UU Kepegawaian.

Artinya, tetap ada hal yang dilakukan yaitu bagaimana reformasi birokrasi ini yang pertama adalah ramping struktur kaya fungsi, dan kita akui beberapa pendahulu kita, bukan sekarang saja itu sudah dilakukan ramping struktur kaya fungsi. Pastinya makin kemari harus makin ramping dan fungsinya makin banyak 71.779 pegawai negeri sipil dengan 68.649 mudah-mudahan saya tidak salah itu PPSU atau PHL-nya memang memerlukan reformasi birokrasi dimana fit and proper test computer assisted test, itu diperlukan sekali... “

Selain bergaya birokratis, Sylvi juga menggunakan gaya retorika formal. Hampir mirip gaya retorika birokrasi namun gaya retorika ini menyiratkan legitimasi. Sylvi menggunakan gaya retorika formal untuk menanggapi jawaban dari calon lainnya soal keuangan negara. Sylvi menggunakan pendekatan UU untuk mengkritisi legitimasi tindakan Paslon 2 yang seharusnya berdasarkan UU Keuangan Negara:

"Ini pengalaman. Saya

tahu betul kalau bicara keuangan negara. Ada UU 
Keuangan Negara No 17 tahun 2003, khususnya pasal 3 dan ayat 6: semua pendapatan daerah dan alokasi daerah harus masuk dalam APBD yang disepakati bersama antara gubernur dan DPRD DKI Jakarta. Tapi saya melihat di sini bagaimana bisa dilaporkan ke DPRD Jakarta sementara harmonisasi diantara eksekutif dan legislatif Jakarta tidak terjadi...”

Gaya retorika Sylvi yang lebih

birokratis dan resmi bisa dimaklumi karena dia adalah kandidat berlatar belakang pemerintahan, bahkan pemerintahan Provinsi DKI sendiri. Sylvi terlihat sengaja dipasangkan dengan AHY untuk mengimbangi posisi AHY yang "buta" tentang peta pengelolaan pemerintahan sipil khususnya Pemerintah Provinsi DKI. Pengalaman puluhan tahun bekerja sebagai aparatur sipil di Pemprov DKI -bahkan sempat menjabat Walikota Jakarta Pusat-menjadikan Sylvi paham kekurangan pemerintahan Basuki-Djarot.

$$
\text { Secara dominan Sylvi }
$$

menggunakan retorika bergaya birokrasi dan resmi atau formal, namun dia juga sempat beretorika dengan gaya nasihat.
Gaya retorika nasihat yang mengedepankan problem dan tindakan yang perlu diambil ini bisa dicermati dari argumen Sylvi berikut ini:
"300 ribu rumah dibutuhkan di Jakarta. 1000 ha wilayah kumuh. Kami bergerilyadi 267 kelurahan 44 kecamatan. Ketika kami ke rumah susun, mereka mengatakan kenapa kami yang sudah begitu lama harus menyewa dan menyewa? Kemudian ketika tidak bisa bayar mereka diusir. Sudah dipindah dari rumah dan akar budayanya. Dia juga sudah terusir dari rusunanwanya. On side upgrading adalah menata kota Jakarta tanpa menggusur. Komitmen. Ini yang harus kita benahi. Ini dalam arti kita bekerja dengan hati."

\section{C.3 Gaya Retorika Basuki Tjahaja Purnama}

Berbicara gaya retorika Basuki

Tjahaja Purnama alias Ahok, sulit untuk mengatakan gaya retorika mana yang dominan. Ahok tidak terlalu menggunakan patron konsisten dalam menata retorikanya untuk berkomunikasi dalam debat publik ini. Sebaran gaya retorika Ahok untuk debat 1 meliputi terbuka, formal, birokrasi, 
maupun nasihat. Sedangkan untuk debat

kedua Ahok baru sedikit lebih konsisten

menggunakan gaya retorika terbuka dan

birokrasi. Gaya retorika terbuka Ahok bisa

dicermati dari argumennya berikut ini:

"Membangun Jakarta itu

visi terutama adalah

membangun manusianya.

Membangun manusia

harus dengan indikator

terukur. Kita kenal

IndeksPembangunan

Manusia supaya sejajar dengan dunia. Supaya di 2015 misalnya Jakarta mencapai IPM 78,99.

Artinya kurang dari 1,01 kita telah mencapai tingkat dunia yang tinggi. Nah, untuk mencapai visi itu, misi utama adalah birokrasi harus melayani dengan konsep yang bersih, transparan, dan profesional. Karena kami sangat yakin, tanpa pejabat publik, tanpa birokrasi yang bersih transparan dan profesional, tidak mungkin program sosial ekonomi atau program apapun tercapai, Maka kami sangat yakin, yang paling utama dibereskan adalah birokrasi dengan rekam jejak pejabat yang jelas dengan bersih, transparan dan profesional. Nah tentu saya juga memaklumi selama 4 tahun lebih ini banyak warga Jakarta hanya melihat penampilan saya terlalu menggebugebu, terlalu semangat. Akibatnya visi-misi yang sudah kami capai, program yang sudah terukur hilang. Sebagian melihat saya terlalu temperamental. Tapi saya juga bersyukur sebagian orang Jakarta melihat hasil nyata, sungai lebih bersih, semua kelihatan. Pelayanan lebih baik. Saya bersyukur punya Mas Djarot. Yang melihat yang telah apa saya kerjakan. Saya juga belajar dari Mas Djarot. Supaya saya juga miripmirip beliau. Supaya kalau kami dilanjutkan lagi, bukan hanya visi-misi program yang tercapai. Tapi Ahoknya sudah menjadi ikon 7.I7 bukan pentium lagi kalau komputer.”

Gaya retorika terbuka merupakan kebalikan dari gaya retorika tertutup. Jika tertutup lebih defensif, maka terbuka lebih spontan serta kurang terprogram. Penyampaian Ahok lebih ke arah spontan. Ahok dalam penyampaian pernyataan awal tidak hanya fokus pada program tetapi juga menyinggung karakter dan gaya kepemimpinannya. Spontan bisa dilihat dari pernyataan yang tidak terstruktur kalimatnya , melainkan “serabutan” dan pemberian contoh yang tidak biasa seperti penggunaan contoh spesifikasi komputer. 
Sebagai petahana bersama Djarot Saiful Hidayat, yang menjadi andalan pasangan incumbent adalah penjabaran keberhasilan atau apa yang sudah dikerjakan. Hal ini tentu saja menjadi kelebihan yang dijual petahana. Ahok menggunakan formula penjabaran keberhasilan dan pencapaian di beberapa pernyataannya. Penyebutan hal-hal yang dianggap keberhasilan digunakan Ahok untuk meng-counter sindirin maupun kritik paslon lain. Contoh, Ahok menyampaikan program yang sudah dijalankan untuk meng-counterprogram paslon 1 yang memberikan dana bergulir pendidikan sebesar Rp 400 ribu. Sekaligus mengkritik paslon lain yang mengkritisi tindakan paslon 2 (Ahok -Djarot ) menggusur warga di bantaran sungai.

Dengan latar belakang petahana yang juga berarti berasal dari lingkungan birokrasi, Ahok menggunakan pula retorika bergaya formal dan birokrasi. Gaya retorika formal bisa dicermati ketika Ahok menjelaskan peraturan keuangan terkait kemunculan program dana bergulir paslon 1 serta mengkritisi program kartu paslon 1 . Penggunaan gaya retorika formal digunakan Ahok dengan pendekatan legitimasi peraturan untuk mengkritisi program kartu tersebut:

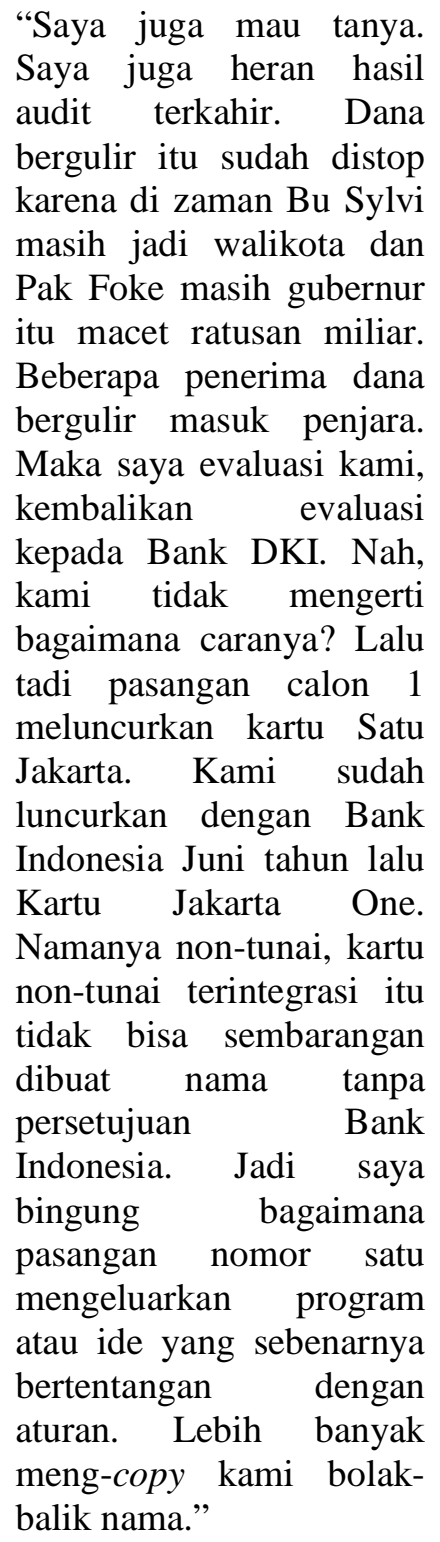

Sedangkan gaya retorika birokrasi digunakan Ahok untuk 
menjelaskan dengan pendekatan

teknis terkait peraturan, kebijakan

Pemrpov DKI. Hal ini juga terkait

pembahasan kartu paslon 1, dan bisa

dicermati dari pernyataan berikut:

\begin{abstract}
"Pasangan nomor 1 ini
kelihatan tidak ngerti peraturan keuangan. Kita kerja sama dengan OJK juga. Kami ingin seluruh Jakarta ini cashless society . Makanya OJK dan BI mengeluarkan rekening bank tabunganku. Setor Rp 20 ribu di bank besar boleh buka rekening. Nah kenapa kartu Jakarta One itu sudah jalan, ini soal cetak saja. Kenapa BI memberi izin karena kami sudah memiliki data base. Semua KJP ada 692 ribu pemegang. Semua pemegang rumah susun, semua yang naik Transjakarta, semua UMKM, semua PKL kami daftarkan. Nah karena itulah BI mengizinkan kami menerbitkan kartu Jakarta One dan bank-bank yang lain sudah MoU baik BCA, Mandiri. Mereka mendukung. Jadi saya kira kurang mengerti peraturan keuangan.”
\end{abstract}

Penggunaan retorika nasihat juga dipakai Ahok, namun berbeda bentuk. Jika retorika nasihat menggambarkan problem yang sedang muncul, namun Ahok merubah statement-nya untuk mengubahnya menjadi sesuatu yang bersifat akan dicapai atau dikerjakan sesuai

- posisinya sebagai petahana. Hal ini bisa

dilihat dari statement Ahok yaitu :
"Mengenai pendidikan yang perlu kami lakukan adalah membuat angka partisipasi murni meningkat. Makanya dibanding tahun kemarin kita naik lebih tinggi dari nasional. Kita juga terus melatih guru sehingga kita harapkan lima tahun kedepan kita bisa masuk 30 besar dari sistem yang ada di dunia. Terus sertifikasi. Kami memiliki visi-misi program, semua terukur dengan angka. Sebetulnya bagi kami suka debat seperti ini, kami harapkan ada masukan baru untuk kami memperbaiki jika diberi kepercayaan kembali. Tapi terus-terang dari tadi kami mencatat banyak sekali yang disampaikan bukanlah sesuatu yang baru. Misalnya mesti ada pusat olahraga, pusat budaya. Kami telah menyelesaikan 188 lokasi ruang publik terpadu ramah anak lengkap dengan pusat olahraganya. Ketika Pak Anies mengatakan tidak berani menutupAalexis, wah kami sudah menutup Stadium dan Miles. Begitu ketemu narkoba kami tutup....”

Gaya retorika terbuka dengan fokus pencapaian hasil juga digunakan Ahok pada debat kedua. Gaya terbuka Ahok lebih disebabkan karena sifatnya spontan, kurang terprogram dalam mengungkapkan 
jati diri. Hal ini bisa dicermati dari

statement berikut:

"Banyak sekali orang yang berfpikir kami ini one man show, kerja bukan tim. Kami ini bukan Superman, kita ngurusin 72 ribu pegawai. Bagaimana mungkin kita mengurusi sungai di Jakarta, orang bisa begitu puas, begitu bersih. Sampah bisa begitu bersih. Pelayanan satu pintu terpadu kami bisa begitu baik. Saya temukan banyak PNS yang naik eselon II yang bersyukur kepada kami. Dia katakan dia tidak pernah merasa begitu bangga jadi PNS. Justru ketika bapak jadi gubernurlah ada kebanggaan buat kami. Kami bisa umrohkan keluarga, kami yang tidak pernah kepikir yang jujur bisa naik eselon II. Dengan seleksi promosi terbuka yang bapak lakukan, kami yang tidak pernah mimpi jadi eselon II dan kami membawa uang yang banyak sekali sekarang. Dan ini halal. Ini yang membuat kami yakin yang kami lakukan sesuai amanat UU ASN. Yang tidak senang tentunya ada. Orang-orang yang kinerjanya tidak memenuhi syarat... Jadi semua PNS ada. Lalu orang merasa kok saya main pukul, tidak merangkul. Mungkin orang tidak banyak yang tahu. Hampir semua pernikahan pegawai rendah di DKI saya hadir Sabtu Minggu. Bahkan kami mengajak nonton bersama. Bagaimana mungkin Jakarta bisa bersih kalau pegawai-pegawai tidak berkerja dengan hati. Bukan karena takut tapi karena mereka merasa ini Jakarta kami bersama.“

Dalam statement ini Ahok lebih menyebar dalam menyampaikan apa yang ia kerjakan dalam alur yang tidak sistematis untuk menjelaskan kinerja birokrasi di pemerintahannya. Kebirokratisan Ahok juga muncul dalam retorikanya di debat kedua. Ahok dengan latar belakang pengalaman memimpinselama 5 tahun --baik sebagai wakil gubernur maupun gubernur-menjelaskan secara teknis kebijakan, program maupun aturan yang ia gunakan.

Hal ini bisa dicermati dari statementberikut:

"Saya mungkin salah satu orang yang beruntung. Saya mantan anggota DPR RI Komisi II yang membidangi membuat UU Diskresi ini. Lalu hubungan dengan koefisien luas bangunan ini apa yang terjadi di Jakarta? Itu ada perda, kalau dilintasi transportasi massa berbasis rel maka koefiesien luas bangunan boleh ditinggiin. Ini mesti dicatat baik-baik. Kalau tidak, dia tidak boleh naikkan. Anda mau teriak 
bayar Rp 1 triliun pun tidak bisa. Karena ini ada perda. Lalu yang menjadi masalah, bagaimana sekarang? Ternyata ketika KLB diizinkan dinaikkan sekarang karena berbasis rel penumpangnya banyak. Tidak ada pengaturan dari UU Administrasi untuk menerima uang tunai kedalam APBD. Lalu bagaimana? Tambah untung kita tidak dapat untung, nah disitulah kita mengenakan kontribusi tambahan dengan dasar perjanjian kerja sama. Kami telah menerima hampir Rp 3,8 triliun dalam bentuk uang komitmen, dengan cara apa? Setelah dia membangun infrastuktur, trotoar, seperti Semanggi. Saya bisa tunjukkan. Ini Semanggi kita bangun Rp 400-an miliar dari uang kontribusi orang menaikkan bangunan di sekitar Semanggi. Kenapa Semanggi bisa dinaikkan begitu tinggi, karena dilewati MRT. Ini Rp 400 miliar. Nanti mencatatnya bagaimana? Kita gunakan perusahaan penilai. Setelah mendapat nilai berapa itu dibukukan di APBD sebagai aset sebagai pendapatan lainlain. Jadi ini sangat jelas tetap berdasarkan good governance dan tranparansi. Itu motto kami.”

\section{C.4 Gaya Retorika Djarot Saiful Hidayat}

Sebagai kandidat petahana, Djarot

lebih mengedepankan gaya retorika

birokratis. Ia lebih sering menjabarkan hal-

hal teknis, pencapaian maupun

keberhasilan. Hal tersebut bisa dicermati

dari statement Djarot berikut :

"Sistem transportasi yang kita bangun adalah subsidi silang. Mereka yang mau naik kendaraan umum dengan harga yang murah. Rp 3.500 dan bahkan beberapa bebas gratis. Pegang KJP gratis, buruh dengan UMP gratis, lansia gratis. Ini hasil yang kita kumpulkan dari pajak. Pajak dari mobil-mobil mewah. Kalau orang kaya masuk lebih baik kita terapkan jalan berbayar. Dengan cara seperti itu pertumbuhan motor di Jakarta akan bisa kita tekan. Sekarang 4.500 motor tiap hari."

Gaya retorika birokratis yang

lebih mengedepankan pencapaian

keberhasilan juga dipakai Djarot

seperti berikut:

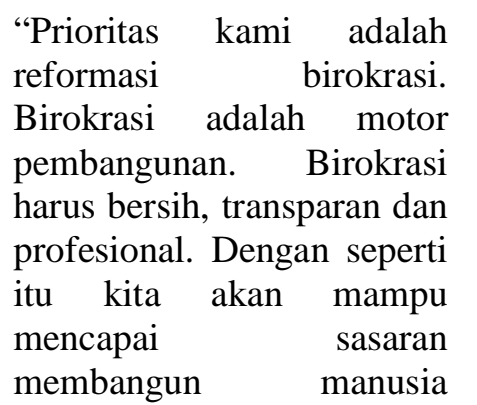


Jakarta. Manusia Jakarta yang kita bangun adalah otaknya harus penuh. Perutnya juga harus penuh. Dompetnya juga penuh. Kalau otaknya penuh berarti otaknya cerdas. Dia berkarakter dan mempunyai daya beli tinggi. Ini hanya bisa dilalui kalau birokrasinya bener-bener bersih dan melayani serta profesional. Sekarang sudah tidak ada lagi ketika tahun ajaran baru ibu-ibu datang ke pegadaian. Sekarang juga tidak ada keluhan tidak mampu ke rumah sakit karena biaya rumah sakit kalau kelas 3 ditanggung pemeritah DKI. Mereka yang kebetulan sakit di rumah butuh pertolongan, pemerintah akan hadir untuk mereka.”

Gaya retorika nasihat juga muncul dalam statement Djarot di debat 1 Pilkada

DKI. Dalam retorikanya Djarot memberikan masukan terkait kondisi Jakarta sebagai yang harus tampil baik dan warga yang hidup lebih manusiawi. Djarot menggeser retorika nasihatnya yang seharusnya berupa tindakan menjadi tindakan yang sudah diambil untuk selanjutnya dimaknai sebagai keberhasilan. Hal ini bisa dicermati dari statement berikut ini :

"Jakarta adalah ibukota, dimana warganya tidak boleh tinggal di bantaran sungai. Tidak boleh di kolong-kolong jembatan yang setiap saat kebanjiran. Mereka melahirkan generasi. Sungguh tidak manusiawi kita membiarkan saudara-saudara kita berpuluh-puluh tahun tinggal di bantaran sungai. Di kolong-kolong jembatan. Maka kami berkomitmen menyediakan rusun yang layak huni ukuran $36 \mathrm{~m} 2$, ada dua kamar, ada pipa gas. Kita juga menyubsidi kehidupan, pendidikannya kita tanggung, kesehatannya kita tanggung. Transportasi kita tanggung. Gaya hidupnya kita tanggung. Subsidi barang kebutuhan pokok. Dengan cara seperti itulah masyarakat Jakarta manusiawi. Tidak heran kalau Indeks Pembangunan Manusia di Jakarta paling tinggi se-Indonesia. Kita juga tidak heran kemiskinan di jakarta 3,75 terendah seIndonesia. Kebijakan ini harus kita ambil. Di samping kita akan menormalisasi sungai dan banjir sudah berkurang. Di samping itu kita memberikan aspek legal kepada mereka yang tidak legal menempati bantaran sungai untuk pindah ke rusun. Kehidupannya kami jamin. Kehidupan mereka kami jamin dan kehidupan generasi penerusnya kita akan jamin. Rusun-rusun kita ada masjid di situ, ada tempat bermain. Supaya mereka tumbuh dengan baik.”

Gaya retorika birokratis juga dimunculkan Djarot pada debat kedua. 
Secara jumlah memang Djarot lebih sedikit penampilannya dibanding Ahok.

Dengan gaya birokratis Djrot banyak berstatement tentang bagaimana paslon 2 melakukan penataan. Seperti yang ia katakan berikut ini:

$\begin{array}{lrr}\text { “Tugas utama birkorasi } \\ \text { adalah melayani } & \text { warga } \\ \text { mulai dari } & \text { dalam } \\ \text { kandungan, lahir } & \text { sampai } \\ \text { meninggal. } & \text { Jakarta } \\ \text { mempunyai } & 135.222 \\ \text { pegawai baik PNS } & \text { maupun } \\ \text { non-PNS dengan } & 5.046 \\ \text { jabatan. } & \text { Kami } & \text { akan }\end{array}$
memastikan mereka bekerja maksimal melayani warga Jakarta dengan hati. Oleh sebab itu diperlukan ukuran yang jelas, salah satunya indikator kinerja. Indikator kinerja akan mengukur bagaimana dia melaksanakan

kewajibannya melayani warga Jakarta. Ukuran ini dilakukan setiap bulan terkait tunjangan kinerja daerah. Dengan cara itu akan ada kompetisi diantara mereka untuk mencapai tunjangan kinerja daerah maksimal. Artinya apa? Mereka tidak perlu lagi korupsi sehingga pelayanan warga Jakarta betul-betul bebas pungli.... Untuk promosi, mutasi dan demosi ukurannya jelas. Kita sangat sabar. Beberapa kali kita berikan peringatan, masukan, jangan korupsi. Warga Jakarta butuh pelayanan cepat, tepat, profesional dan bebas pungli. Apabila ada yang lambat, dengan menyesal dengan senang hati juga kami akan ganti. Oleh sebab itu, untuk pergantiannya kita membikin dengan cara lelang terbuka.”

Sedangkan untuk berbicara pendidikan, Djarot menutup permasalahan yang dihadapi DKI terkait Angka Partisipasi Aktif yang masih dikisaran 67 \% dengan membandingkan APM di tingkat nasional yang hanya 59 $\%$, kemudian melanjutkannya dengan apa yang akan dilakukan selanjutnya.

\section{C.5 Gaya Retorika Anies Baswedan}

Anies Baswedan adalah mantan menteri pendidikan di era presiden Joko Widodo. Ia penggagas kegiatan Indonesia Mengajar yang membuat namanya melambung. Anies menggunakan pendekatan berbeda dalam 2 debat ini. Pada debat 1 Anies lebih menonjolkan personal brandingdengan lebih banyak beretorika untuk menumbuhkan persepsi tentang dirinya sekaligus persepsi tentang apa yang ia cita-citakan. Pada pembukaan debat, Anies membangun persona diri dan 
pasangannya sebagai orang yang

berpengalaman. Anies menyampaikan,

paket paslon ini datang dengan track record masing-masing yang sudah mumpuni mengurusi Jakarta. Anies membangun karakter dirinya berdasarkan cita-cita, tujuan, nilai, keunikan yang ia miliki seperti ingin menghadirkan kota maju, bahagia, aman dan damai.

Di kesempatan lain Anies membangun branding soal programprogram unggulannya yaitu OK OCE. Sebagai program unggulan, OK OCE terus diinisiasi dalam debat publik agar keuggulan program ini dikenal publik. Personal brandingbertujuan mengeksplorasi program OK OCE sebagai trade mark paslon 3. Anies membangun persepsi bahwa paslon ini ingin menawarkan cara pandang berbeda dalam melihat persoalan Jakarta, misalnya persoalan memerangi kemiskinan. Ini bisa dicermati dari statement Anies yang menyatakan :
"Kita mendengar, pasangan pertama memberikan ikannya. Pasangan kedua memberikan kailnya. Ikan dan kail baik diberikan, tapi jika kolamnya masih ada. Bagian kami memastikan kolamnya masih tersedia. Apalah artinya ikan dan kail kalau kolamnya habis. Kita tidak mendekati masalah kemiskinan sebagai masalah sosial tapi masalah peningkatan kesejahteraan. Kami tidak memerangi kemiskinan. Pendiri republik ini tidak pernah memerangi kemiskinan. Mereka mengatakan memajukan kesejahteraan umum, mereka mengatakan mencerdaskan kehidupan bangsa. Mereka tidak mengatakan memerangi kebodohan. Optimisme pesan positif. Dan disini kami menghadirkan 44 pusat pertumbuhan ekonomi di Jakarta yang akan menumbuhkan lapangan pekerjaan. Karena itu program OK OCE yang tadi disampaikan Bang Sandy lebih dari sekadar menumbuhkan wirausaha. Ini program pertumbuhan ekonomi yang akan menyiapkan lapangan pekerjaan. Jakarta adalah kota dimana perekonomian Indonesia berpusat. Kita gerakkan sektor swasta, bekerja bukan yang besarbesar saja...”

Aspek personal branding Anies juga menyiratkan sindiran maupun kritik kepada paslon lain. Misalnya dalam kasus penggusuran, Anies mengritik paslon 2 
yang menjalankan rencana penggusuran di

Bukit Duri Jakarta. Anies bermain dengan

persepsi bahwa dirinya hadir bersama

dengan warga korban pengggusuran.

Retorika sebagai ahli di bidang pendidikan juga ditampilkan. Persoalan pendidikan menjadi hal yang dicap sebagai spesialisasi Anies. Anies memainkan personanya sebagai “ahli” pendidikan. Anies beretorika bahwa pendidikan bukan sekedar persoalan tentang sekolah. Anies mengkritisi visi paslon 2 yang mengedepankan membereskan otak, perut, dan dompet sedangkan soal moral dan akhlak tidak menjadi perhatian. Anies beretorika bahwa pendidikan lebih mementingkan soal karakter dan moral dibanding persoalan angka partisipasi. Anies memaparkan bagaimana dia akan membangun pendidikan yang memfokuskan pembangunan karakter. Anies menyisipkan program yang identik dengan dirinya, yaitu Indonesia Mengajar dengan pemberian contoh mengundang profesional, mahasiswa, untuk mau mengajar ke kampung-kampung di Jakarta.

Anies menciptakan persepsi bahwa membangun karakter akan membangun akhlak dan membangun karakter akan mendorong kota menjadi kota yang bahagia. Ini bisa dicermati dari statement Anies berikut ini:

$\begin{array}{lr}\text { "Begitu kita } & \text { berbicara } \\ \text { meningkatkan } & \text { mutu }\end{array}$ pendidikan, maka bukan hanya persekolahan. Tentu sekolah harus dibereskan. Tapi jangan lupa visi menjadi penting. Visinya bicara tentang saya catat perut otak dan dompet. Disana tidak ada moral, tidak ada karakter, di sana tidak ada nilai. Justru yang mau kita bangun adalah iman, takwa, akhlak, karena yang dibutuhkan bagi indonesia adalah pendidikan yang menumbuhkan karakter moral dan karakter kinerja. Karakter moral artinya jujur, ikhlas, tuntas beriman. Tapi karakter kinerja artinya kerja keras, tuntas. Pendidikan bukan sekedar penyiapan pekerjaan. Pendidikan bukan sekedar angka partisipasi... Tetapi yang tidak kalah penting di lingkungan. Kita akan tetapkan lingkungan menjadi lingkungan belajar. Maghrib sampa isya bagi yang muslim mengaji. Kita akan gunakan menjadi jam belajar bagi seluruh 
peserta didik di Jakarta.

Anak anak belajar, dan

kami akan undang profesional, mahasiswa, mari turun ke kampungkampung. Jadilah saudara bagi adik-adikmu. Bimbinglah mereka belajar di sore hari.”

Anies membangun persepsi bagaimana pemimpin seharusnya berperilaku dan memimpin. Ia memberikan gambaran bagaimana pemimpin harusnya bisa berdialog sekaligus tegas. Tentu saja ini lagi-lagi untuk mengkritisi Ahok sebagai petahana yang dianggap tidak mampu menghadirkan kepemimpinan yang baik. Anies membangun persepsi dirinya lebih bisa menghadirkan keadilan sesuai tema besar dari paslon 3 yaitu berkeadilan. Pemberian contoh Alexis, Anies mencoba membangun branding ketegasan dengan jalan mengkritisi dan menyindir paslon 2 sebagai petahana yang dianggap hanya tegas dalam penggusuran namun tidak tegas dalam penertiban prostitusi di Alexis.
Anies mencoba bermain di wilayah teknis. Anies memainkan gaya retorika birokratis untuk menguji paslon lain. Anies mencoba menyentuh persoalan teknis untuk menguji paslon 1. Penggunaan pendekatan bergaya birokrasi bisa menimbulkan mis-interpretasi. Misalnya penggunaan Tim Pora yang bagi orang awam menimbulkan tanda tanya. Ini digunakan untuk menguji paslon 1 . Hal ini bisa dilihat efeknya ketika paslon 1 memberikan jawaban dan setelah itu Anies menanggapi jawaban tersebut. Sebagai efek dari pertanyaan Anies sebelumnya yang bergaya birokrasi, Anies menanggapi jawaban paslon 1 bahwa jawaban tersebut tidak tepat. Anies menyatakan yang dimaksudkan Tim Pora adalah tim pengawasan orang asing. Anies ingin menunjukkan ketidakmampuan paslon 1 memahami persoalan di ranah birokrasi pemprov DKI. Ditambah dengan statement: 
semua. Ibu Sylvi adalah

bagian dari pemerintahan”.

Dengan gaya birokrasi pula Anies

mengkritisi paslon 2 sebagai petahana

dengan statement:

”RT RW akan kita
kembalikan perannya. RT
RW yang dipangkas
sekarang untuk pengurusan
KTP kita pastikan. Yang
kedua, pengawasan melekat
disetiap wilayah sehingga
memastikan mereka yang
berkarya di Jakarta adalah
yang memiliki dokumen
lengkap karena sekarang
berdatangan dari luar.
Mengambil manfaat di
Jakarta dan merugikan
warga Jakarta. Tim Pora
akan kita optimalkan.”

Ungkapan ini menunjukkan bahwa

dalam pemerintahan petahana peran RT

RW mulai tidak maksimal. Sehingga di

bawah pemerintahan Anies-Sandi

nantinya, peran RT RW akan

dioptimalkan. Dalam debat kedua, Anies

memainkan gaya retorika nasihat maupun

birokrasi. Dengan gaya yang kuranglebih

seperti “perkuliahan” Anies memberikan

“kuliah” dalam menata Jakarta:

"Sekarang kita masuk eraopen governance dimana pemerintah dan masyarakat bekerja bersama membangun wilayah.

Pendekatan ini membuat aparatur dan warga negara

bekerja bersama. Itu pertama. Yang kedua, tidak hanya dengan memberi iming-iming tunjangan kinerja. Itu baik karena memberikan carrot dan stick-nya jika tidak perform. Tapi yang tidak kalah penting adalah budaya kerja. Pemimpin harus merangkul bukan memukul. Pemimpin harus mendorong motivasi bukan menurunkan motivasi. Jadi yang dilakukan untuk membereskan persoalan kompetensi itu, satu, libatkan publik, dua pemimpinnya memberi arah yang memotivasi, tiga, siapkan pelatihan yang terus-menerus sesuai bidangnya. Karena itu menghadapi persoalan kompetensi kita bisa lakukan dengan membangun budaya yang sehat, partisipasi publik, dan memberi ruang untuk pengembangan diri.”

Gaya retorika ini merupakan gaya retorika nasehat. Anies memberikan problem dan tindakan apa yang diambil sebagai solusi. Ini juga dicermati dari statement Anies terkait soal kemacetan dan problem air:

"Problem kemacetan di Jakarta karena kita semua mayoritas menggunakan kendaraan pribadi. Karena itu solusinya adalah memfasilitasi kendaraan 
publik massal. Bukan hanya

kendaraan publik.

Kendaraan publik massal.

Kalau hanya kendaraan

publik itu bisa ojek, itu

kendaraan publik tapi tidak

massal. Arahnya kemana?

Arahnya ke penggunaan seperti busway, bis, mini bus, sampai angkot. Yang akan kita bangun adalah sistem transporatsi terintegrasi. Artinya kalau kita membayangkan warga Jakarta seperti badan, maka jalur tranportasi adalah pembuluh darahnya. Bisa mengalir ke seluruh bagian.... Terkait dengan air, yang perlu kita di sini adalah lebih 5 juta warga Jakarta belum mendapatkan air PAM. Karena itu pipanisasi menjadi krusial. Yang akan kita lakukan adalah prioritaskan pada kampung-kampung rumah dengan ukuran dibawah 150 m2."

Personal branding masih dimainkan

Anies dalam debat kedua. Anies membangun persepsi terkait dirinya yang punya latar belakang yang berpengalaman serta jaringan dan menawarkan apa yang akan ia lakukan nantinya.

\section{C.6 Gaya Retorika Sandiaga Uno}

Sandiaga Uno merupakan kandidat dari luar pemerintahan. Ia dikenal sebagai pengusaha sehingga ketika masuk ke dunia birokrat perlu membangun persepsi diri. Ia perlu membangun persona diri. Aspekpersonal branding menjadi lebih dominan dipakai Sandi baik dalam debat pertama maupun kedua. Dengan background pengusaha maka isu ekonomi, penciptaan lapangan kerja dan entrepreneurship menjadi “jualan” Sandi.

Retorika Sandi mengedepankan program sebagai produk unggulan. Program OK OCE didapuk sebagai jawaban atas persoalan Jakarta, mulai lapangan pekerjaan, pendidikan hingga biaya hidup. Sandi membangun persepsi bahwa selama dia berkampanye dan terjun ke lapangan ada 3 persoalan utama yang konsisten dibahas warga. Hal ini bisa dicermati dari statement Sandi yang menyatakan :

“Ada 3 tema yang konsisten diangkat warga. Pertama lapangan pekerjaan semakin sulit. Kedua, masalah pendidikan. Pendidikan kita diharapkan lebih tuntas berkualitas dan terjangkau. Ketiga berkaitan dengan biaya hidup. Kami mempunyai program OK OCE. One Kecamatan One Centre for Entrepreneurship, dimana 
diubah pola pikirnya bahwa

kedepan kita akan

permudah lahan usaha

dengan garasi inovasi. Kita

juga akan permudah kredit

hingga Rp 300 juta. Kita

berikan pendampingan

melalui mentorship. Di

bidang pendidikan kami

juga akan menghadirkan

KJP Plus.Ini adalah

jawaban yang ditunggu

keluarga tidak mampu.

Terakhir untuk biaya hidup, program kami adalah harga OK. Harga OK ini akan memastikan biaya hidup terjangkau khususnya warga menengah ke bawah.”

Sandi memainkan persepsi bahwa

background-nyasebagai pengusaha sudah

membina UKM selama 15 tahun. Selain itu

Sandi juga mengedepankan OKOCE

sebagai jalan keluar. Sandi juga beberapa

kali menggunakan contoh individu untuk

menunjukkan problem warga Jakarta.

Sandi beretorika untuk memunculkan

persona dirinya yang mampu

menyelesaikan masalah eknomi khususnya

lapangan pekerjaan di Jakarta.

"Pertanyaan untuk Pak

Djarot. Angka 10\% itu

dari mana? Saya ini

membina UMKM sudah

15 tahun. Kalau ada

pendampingan, dari 10

pengusaha yang kita create atau kita mulai, ada

$80 \%$ yang sukses.

Kuncinya pendampingan.

Kuncinya mentoring.

Kuncinya itu ada di one

kecamatan one centre for

entrepreneurship. Saya

melihat ada

ketidakberpihakan sistem

sekarang. Yang kaya

makin kaya. Yang miskin

makin miskin. Yang usaha

besar makin besar. Yang

usaha kecil makin

terpuruk. Saya melihat Ibu

Nurhayati di Bukit Duri.

Dia tadinya berjualan nasi

uduk. 12 liter sehari. Tapi

karena kebijakan Pemprov

sekarang tidak

memastikan lahan usaha,

tidak memberikan

permodalan,tidak

memberikan

pendampingan, dia terus tergerus usahanya. Ini yang membuat saya terenyuh. Menurut saya program kami OK OCE bisa menciptakan 200 ribu lapangan pekerjaan baru.

Saya punya pengalaman.

Saya pernah membina beberapa komunitas.

Terakhir kali, dalam dua minggu terakhir, sudah 1500 pengusaha lahir melalui program $\mathrm{OK}$

OCE.”

OK OCE sebagai “jualan” kembali digaungkan Sandi di debat kedua. Sandi ingin menginisiasi program OK OCE sebagai program unggulan untuk menyelesaikan masalah Jakarta. Hal ini 
bisa dilihat dari statement Anies yang

menyatakan:

“Kami memulai program
yang sudah menjadi
gerakan, OK OCE. Apa itu?
One Kecamatan One Centre
for Entrepreneurship. Jadi
ide tadi bukan lagi menjadi
masalah tapi sampah
menjadi berkah. Sampah
dengan program OK OCE
akan menjadi sumber
penghasilan, memiliki nilai
tambah. Banyak sekali
sekarang pengusaha lahir
dari pengelolaan sampah.”

Sandi juga memainkan gaya

retorika nasihat untuk debat kedua

pilkada DKI. Gaya retorika Sandi dengan

nasihat ini berpola menyampaikan

persoalan atau kasus kemudian

memberikan solusi. Ini terlihat ketika

Sandi berbicara tentang penciptaan

lapangan kerja:

"Pelayanan publik itu harus berujung pada penciptaan lapangan pekerjaan. Saya berjalan hampir 1 tahun lebih menemui cerita seperti Mas Noval, pengusaha yang ingin membuka usaha di bidang mice (meeting insentive convention and exhibition).Diamengala mi kesulitan karena perizinannya berbelitbelit. Indeks kemudahan berbisnis di Indonesia yang mana banyak dikotribusi Jakarta masih di posisi 91. Jakarta memiliki tugas sangat berat untuk memberikan kemudahan berbisnis, mudah dan integrated. Bagaimana reformasi birokrasinya? Yaitu reformasi birokrasi yang ramah, efisien dan tranparan.”

\section{Gaya Retorika dan Personal Branding}

Jika dilihat keseluruhan, upaya kandidat baik dalam bentuk argumen yang didasari cara berpikir dan dinyatakan dalam susunan kata dan kalimat yang diucapkan, maka upaya menghadirkan aspek branding dalam diri masing masing kandidat sangat kentara. Sebagai contoh, AHY sebagai calon berlatar belakang militer ingin membranding dirinya sebagai sosok atau tokoh muda yang mampu memimpin “pertempuran” dengan baju sipil. Kemudian Sylvi mem-branding dirinya sebagai birokrat wanita kaya pengalaman yang akan mampu membawa perubahan bagi DKI. Ahok berupaya menunjukkan sosok tegas, ceplas-ceplos namun 
menghadirkan kinerja positif. Demikian pula degan Djarot yang merupakan bagian dari petahana,ingin menunjukkan sisi kalem untuk mengimbangi spontanitas Ahok. Anies mengedepankan branding golongan terdidik denganbackground akademisi dan mantan menteri yang membidangi pendidikan yang ingin terjun membenahi Jakarta, dan dibantu Sandiaga Uno dengan branding pengusaha sukses yang tercermin dari program dan retorikanya yang identik dengan topik ekonomi dan dunia usaha.

\section{Personal branding sangat identik} dengan upaya penciptaan persepsi. Penonjolan hal-hal yang menjadi kekuatan personal seperti penyampaian background militer yang terstruktur dan terencana, penekanan pesan bahwa kandidat bukanlah merupakan bagian dari masa lalu maupun kekuatan atas pencapaian yang sudah dikerjakan, semua disampaikan untuk mempengaruhi aspek psikologis penonton debat.
Gaya retorika nasehat muncul sebagai gaya retorika yang umum dipakai kandidat. Gaya retorika nasehat yang cenderung menyatakan ada masalah dan solusi yang perlu diambil umumnya disampaikan bukan dari petahana, karena penantang ingin menyatakan bahwa apa yang sudah dikerjakan petahana masih belum menyelesaikan persoalan. Sehingga pernyataan tentang kegagalan, persoalan lebih menonjol untuk mengkritisi kinerja petahana.Gaya retorika birokratis dan resmi kentara muncul didebat pilgub dan cawagub DKI karena dalam konteks pemerintahan sipil maka penonjolan aspek peraturan seperti UU, atau teknis birokratis merupakan hal lumrah menjadi pembahasan misalnya terkait aparatur sipil, kebijakan,dll.

Debat sendiri dalam rangkaian kegiatan kampanye setidaknya memiliki 3 fungsi antara lain memuji diri sendiri, menyerang lawan atau membela diri saat diserang. Selain itu ucapan dalam debat setidaknya fokus pada 2 hal, yaitu 
masalah kebijakan atau karakter. Jika diskusi kebijakan berfokus pada perbuatan masa lalu, rencana masa depan, atau tujuan umum sedangkan diskusi tentang karakter berfokus pada kualitas pribadi, kemampuan kepemimpinan, atau cita cita seseorang. (Benoit dalam Kaid, 2015: 276)Lebih jauh Benoit juga menyampaikan,debat lebih menitikberatkan aspek pembahasan tentang kebijakan daripada karakter. Hal yang sebaliknya akan terjadi ketika melihat iklan TV. (Benoit dalam Kaid, 2015: 277) Para kandidat melakukan hal sama dengan gaya retorika yang beragam. Jika membahas tentang kebijakan maka gaya retorika nasihat, birokratis lebih mengemuka. Sedangkan ketika berbicara tentang karakter maka retorika yang berkaitan dengan personal branding hadir sebagai retorika yang mencolok.

Upaya untuk menyerang petahana jelas muncul dari 2 pasangan kandidat lainnya yatu kandidat nomor 1 (Agus Sylvi) dan kandidat nomor 3 (Anies -
Sandiaga), sedangkan upaya memuji diri sendiri muncul dari pasangan kandidat nomor 2 (Basuki-Djarot) sebagai petahana dengan statement yang berisi apa yang sudah dikerjakan dan apa yang dicapai. Sedangkan kritik dari nonpetahana berisi kritik terhadap kebijakan dan kritis atas pencapaian hasil maupun mengkritisi gaya kepemimpinan.

\section{Kesimpulan}

Berbicara gaya retorika dalam kasus pilkada DKI terdapat beberapa poin yang bisa disimpulkan, antara lain seluruh kandidat gubernur maupun wakil gubernur DKI menggunakan kombinasi gaya retorika politik baik dalam debat publik pertama maupun kedua. Artinya tidak ada kandidat yang menggunakan gaya retorika tunggal. AHY dominan menggunakan gaya retorika nasihat namun mengkombinasikan nasihat serta birokrasi.

Sylvi dengan latar belakang birokrasinya menggunakan gaya retorika 
birokrasi, formal/resmi, nasihat. Basuki

Tjahja Purnama alias Ahok menggunakan

gaya retorika terbuka, birokrasi, formal

sedangkan Djarot mengkombinasikan

gaya retorika birokrasi dan nasihat. Anies

Baswedan lebih mengedepankan persoanl

branding dalam debat pertama dan

birokrasi sedangkan di debat kedua,

Anies mengkombinasikan nasihat serta

birokrasi. Sandiaga Uno lebih

mengutamakan aspek personal branding

dengan latar belakang pengusaha.

\section{Referensi}

Benoit ,W.L., \& Harthcock,A. (1999).

Functions of the Great Debates :

Acclaims, Attacks, and Defenses in the 1960 Presidential Debates.

Communications Monographs,66

Cangara, Hafied. (2009). Komunikasi

Politik: Konsep, Teori dan Strategi.

Jakarta: Rajawali Pers.

Heru Ricky, (2015). "Perbandingan Retorika Prabowo Subianto DAN Joko Widodo dalam Debat Calon Presiden 2014(Studi Kasus Retorika Debat Calon Presiden 2014Mengenai Pembangunan Ekonomi dan KesejahteraanSosial). Diunduh dariejournal.uajy.ac.id/6445/

Hendrikus, P. Dori Wuwur. (1991). Retorika. Yogyakarta: Kanisius

Kaid, Lynda Lee. (2015). Handbook Penelitian Komunikasi Politik. (ed
Terjemahan). Bandung: Penerbit

Nusa Media.

Montoya \& Tim Vandehey. (2008). The

Brand Called You. McGraw-Hill

Professional

Montoya, Peter. (2006). The Personal

Branding phenomenon. Nashville:

Vaughan Printing

Nimmo, D. (1978). Political Communication and Public Opinion in America.California: Good Year Publishing Company.

Mc.Quail, Denis. (1987). Teori

Komunikasi Massa. Jakarta:

Erlangga

Turner,L\& West,R. (2007). Introducing Communication Theory: Analysis and Application. Third Edition International. New York: McGrawHill.

Kertanegara, Rizky dan Wahyuni, Tri. (2014). "Gaya Retorika pada Halaman Facebook Peserta Konvensi Calon Presiden Partai Demokrat Dari Latar Belakang Akademisi, Birokrat, dan Militer.”Paper dalam ProsidingPR Dan Marketing Politik 2014, Fikom Universitas Mercu Buana: Jakarta.

Website :

KPUDDKI. (2017). Keputusan KPUProvinsi DKI Jakarta Tentang Tahapan Program Dan Jadwal Penyelenggaraan Pemilihan Gubernur Dan Wakil Gubernur Daerah Khusus Ibukota Jakarta Tahun 2017 Nomor 05 tahun 2016. Diakses dari https://kpujakarta.go.id/info-pilkadadkk. 
